\title{
FENOMÉN ROMANTIZMU VO FILMOVOM DIELE
}

\author{
JÁN SABOL \\ Filozofická fakulta Univerzity Pavla Jozefa Šafárika v Košiciach
}

\begin{abstract}
Abstrakt: Štúdia sa zaoberá vplyvom romantickej poetiky (resp. poetiky romantického obdobia) na audiovizuálnu tvorbu. Autor $v$ tejto súvislosti zmieňuje nielen niektoré filmové adaptácie literárnych predlôh $\mathrm{z}$ obdobia romantizmu, ale poukazuje aj na základné genologické princípy tohto obdobia a $\mathrm{v}$ širšom literárnom a kulturologickom kontexte na kultúrno-spoločenské vplyvy prelomu 18. a 19. storočia na umenie obdobia romantizmu. Štúdia nemá ambíciu komplexne zachytit’ otázky vplyvu romantickej poetiky na audiovizuálnu tvorbu, načrtáva iba niektoré tendencie, ktoré sú badatel’né vo filmovej tvorbe a ktoré majú korene v romantizme, ale tiež v stredovekom umení, ktoré sa stalo vel'kou inšpiráciou pre romantické obdobie.

Klúčové slová: romantizmus, stredoveké umenie, audiovizuálna tvorba, literárna predloha, filmová adaptácia
\end{abstract}

O romantizme nie je možné uvažovat’ ako o konzistentnom umeleckom smere. Má viacero prúdov a línií, od monumentálnosti revolučných ideí až po silný individualizmus spojený s hlbokým senzitivizmom a mysticizmom, ktorý je inšpirovaný svetom stredovekej mystiky a transcendentna a rezonuje predovšetkým v žánroch lyriky. Nemecký filozof Friedrich Schlegel poznamenal, že na definovanie romantizmu by mu nestačilo ani dvetisíc strán, ${ }^{1}$ francúzsky básnik a kritik Remy de Gourmont na margo problému definovania romantizmu dodal, že ,je l’ahšie to cítit, ako o tom hovorit"“2 . Viacerí umenovedci sa prikláňajú k téze, že by sa malo skôr hovorit’ o romantizmoch než o romantizme. ${ }^{3}$ Aj ked' má romantizmus viacero línií, predsa len môžeme vyabstrahovat’ tendencie a základné postuláty, ktoré z umeleckého, ale aj filozofického hl'adiska definujú umelecké, v širšom kontexte kultúrno-spoločenské obdobie prelomu 18. a 19. storočia. Holandský literárny vedec Maarten Doorman v knihe De romantische orde (2004) píše, že romantizmus nie je len umelecký smer, ale aj poňatie života, paradigma, filozofia, spôsob života. ${ }^{4}$

Romantizmus ako umelecké obdobie i filozofické hnutie výrazným spôsobom inšpiruje umelecký priestor prakticky až dodnes. Ked’že problematika, ale aj charakter romantizmu sú rôznorodé, $v$ našej štúdii skúmame iba niektoré z motívov z romantickej literatúry (romantickej poetiky) či v širšom kontexte z romantického obdobia a myslenia, ktorými sa inšpirovala filmová tvorba. Štúdia nemá ambíciu komplexne zachytił otázky vplyvu romantickej poetiky/myslenia na filmové dielo, načrtáva len

\footnotetext{
${ }^{1}$ Pozri ŽITNÝ, M. (ed.). Nemeckí romantici. Bratislava : Tatran, 1989, s. 132.

${ }^{2}$ Cit. podl’a MATUŠKA, A. O romantizme. In ČEPAN, O. (ed.). Litteraria XVI. Bratislava : Veda, 1974, s. 5.

${ }^{3}$ Pozri napr. HRBATA, Z. - PROCHÁZKA, M. Romantismus a romantismy. Praha : Karolinum, 2006.

${ }^{4}$ DOORMAN, M. De romantische orde. Maastricht : Bert Bakker, 2004. Cit. podla českého prekladu: DOORMAN, M. Romantický řád. Praha : Prostor, 2008, s. 16.
} 
niektoré tendencie, akými sa romantizmus konkretizoval v médiu filmového jazyka na úrovni niektorých štýlotvorných, tematických a motivických jednotiek. Zároveň poukazuje aj na obdobie stredovekého umenia, ktoré sa stalo vel'kou inšpiráciou pre romantické obdobie.

\section{Lyrické vs. epické}

Ak hovoríme o romantizme, musíme spomenút jeho základný charakter - fenomén individualizmu, subjektivizmu, existenciu Ja, básnického subjektu odhal'ujúceho rôzne zákutia l’udskej duše. Poézia, v širšom kontexte lyrika, ako dominantný umelecký druh obdobia romantizmu sa vymedzil k opozícii k epickému. ${ }^{5}$ Nemecký filozof Georg Wilhelm Friedrich Hegel poukazuje na to, že lyrická tvorba na rozdiel od epickej neprezentuje javy, veci v ich vonkajškovej podobe, ale podáva „vnútrajškový" ${ }^{\prime 6}$ pohl'ad. Elementárnou vlastnostou, ktorá umožňuje vzájomne interferujúci vztłah filmovej a literárnej štruktúry, je epický charakter literárneho (prozaického), ale aj filmového diela. Synkretický spôsob kreovania umeleckej skutočnosti je markantný pre filmovú tvorbu, v ktorej sa spája a kreuje syntéza divadelných, výtvarných (fotografických), literárnych, hudobných (v širšom zmysle slova akustických) prvkov. Sujetový charakter filmového a prozaického diela vytvára príležitost' k adaptáciám pôvodných literárnych textov, ktoré sa stávajú vhodným prototextom vo vztahu $\mathrm{k}$ filmovému metatextu.

Z genologického hl'adiska môžeme poznamenat', že aj ked' je elementárnou bázou filmového rozprávania existencia epického pôdorysu, na výslednom tvare sa podiel’ajú prvky charakteristické aj pre dramatickú a lyrickú štruktúru. Filmové dielo sa tak stáva stavbou, na ktorej kreovaní sa zúčastňujú nielen prvky viacerých typov umenia, ale z genologického aspektu aj segmenty všetkých troch druhových zložiek. ${ }^{7}$ Akákol’vek estetická „,informácia“ tak môže mať charakter viac či menej lyrický, viac či menej epický alebo viac či menej dramatický, ide len o mieru koherencie, interferencie $\mathrm{v}$ danom okamihu.

V týchto súvislostiach môžeme sledovat’ zaujímavú koreláciu epických a lyrických postupov, lyricko-epickú konfrontáciu napríklad vo filme Luca Bessona Jana z Arcu (The Messenger: The Story of Joan of Arc, 1999). Snímka je výrazne inšpirovaná

\footnotetext{
${ }^{5}$ Podl’a G. W. Hegela je lyrika totalitou subjektu, zatial' čo epika totalitou objektu.

${ }^{6}$ Tento pojem používa Hegel vo svojej knihe Ästhetik (1835) a dodáva: „Poetická fantázia ako básnická činnost’ nám nezobrazuje ako plastika samu vec vo svojej - aj ked’ umením vytvorenej - vonkajšej realite, ale podáva o nej iba vnútrajškový názor a cit. Už v tomto najvšeobecnejšom spôsobe produkcie prejavuje sa subjektivita duchovnej tvorby a stvárňovania ako najvýraznejší prvok dokonca aj v tých najnázornejších podaniach oproti výtvarným umeniam. " Cit. podl’a slovenského prekladu: HEGEL, G. W. Estetika II, Bratislava : Epocha, 1970, s. 323. Deleuze v tomto kontexte píše, že lyrická abstrakcia nezachytáva ducha v boji, ale to, že tento druh je postavený pred alternatívu. Lyrická abstrakcia teda nie je postavená na akcii a dynamike, ale vytvára atmosféru meditácie subjektu. Pozri DELEUZE, G. Cinéma I: L'image-mouvement. Paris : Edition de Minuit, 1983. Cit. podl’a českého prekladu: Film 1. Obraz-pohyb. Praha : Národní filmový archiv, 2000, s. 139 .

${ }^{7} \mathrm{~V}$ týchto úvahách nadväzujeme na tézy švajčiarskeho literárneho vedca Emila Staigera publikované v práci Grundbegriffe der Poetik (1946), ako ich vo svojej publikácii Estetické paralely umenia rozpracoval slovenský literárny vedec a estetik Július Pašteka: „Povedzme to s použitím Staigerovej formulácie: literárne dielo, ktoré by bolo ,celkom epické ${ }^{\prime}$ alebo ,celkom dramatické', je nemyslitelné, pretože každé literárne dielo má podiel na všetkých druhoch a len isté ,viac' alebo ,menej'rozhodne o tom, či toto dielo nazveme ,epickým’, ,dramatickým’ alebo ,lyrickým’." Pozri PAŠTEKA, J. Estetické paralely. Bratislava : Veda, 1976, s. 167.
} 
základnými romantickými postulátmi: heroizmom, symbolikou stredovekej spoločnosti, romantickými činmi hlavnej predstavitel'ky nesúcej jednu zo základných ideí romantizmu, ktorou je boj za slobodou, ale zároveň s tragickým romantickým naplnením jej osudovosti. V záverečnej časti filmu, ked’ postava Johanky čaká vo väzení na vynesenie rozsudku, odohráva sa až faustovsky rozhovor medzi ňou a jej víziou postavou inšpirovanou Goetheho Mefistom, ktorá relativizuje jej životné poslanie. Johankino vnímanie reality je postavené na ikonickej percepcii reality: znak ako symbol (tanec, zvuky, meč hodený v tráve). Postava, možno ju nazvat’ pokušitel’om, využíva, povedané termínom ruského filozofa Jurija Lotmana, operatívnost komunikácie ${ }^{8}$. Interpretácia predmetov (znakov) využíva teda operatívnost’ ako princíp percepcie reálnej skutočnosti. Meč hodený v tráve nie je symbolom vzdoru, výzvy, boja, je len vecou hodenou v tráve.

Pokušitel: „Chceš povedat', že Boh povedal: ,Potrebujem t’a Johanka?'“ / Johanka: „Nie, ale poslal mi znamenia.“ / pokušitel: „Znamenia? Aké znamenia?“ / Johanka: „Vietor.“ / pokušitel': „Vietor?“ / Johanka: „Mraky, zvony.“ / pokušitel': „Mraky, ktoré zvonia?“ / Johanka: „Tanec. Ten tanec.“ / pokušitel: „Tanec?“ / Johanka: „Meč ležiaci v tráve. To bolo znamenie.“ / pokušitel': „Nie. To bol meč v tráve.“ / Johanka: „Nemohol sa tam len tak objavit'. Nemohol. Meč sa nemôže sám len tak objaviț." / pokušitel': „Pravda. Každá pravda má nekonečne vel’a príčin, tak prečo jednu nevybrat?? ... [Nasleduje vizualizácia: vojak zahodí meč do trávy, stratí ho pri súboji.] „Ty nevieš, čo sa stalo, Johanka. Videla si to, čo si chcela vidiet."

Citovaná filmová pasáž poukazuje na prozaickú priamočiarost’, akcentáciu konkrétneho, hmatatel'ného, a zároveň útočiaceho na lyrické „slabiny“ ikonického vnímania reality. Zo semiologického hladiska lyrický princíp inklinuje ku konotácii, zatial” čo epický k denotácii. Náznakovost' lyrickej konotácie pritom znamená priblíženie sa k označovanému predmetu nie cez priame pomenovanie, ale akousi oklukou, básnickým obrazom. Vo vzt’ahu epické - lyrické vo filmovom diele tak prichádza k determinatívnemu syntagmatickému vztahu, pričom intenzita využívania lyrického smerom k epickému určuje aj mieru subjektivizácie diela. Základnou vlastnostou epiky je jej sujetovost', lyrika túto sujetovost’ oslabuje, posilňujúc skôr líniu simultánnosti. Preto aj miera entropie v lyrike je väčšia než v epike, čo, prirodzene, súvisí s výrazným pertraktovaním subjektívneho, ktoré môže vyvolávat’ intenzívnejší emocionálny efekt než je to pri epike. Epika je charakterizovaná predovšetkým zachytením objektívneho sveta, je pre ňu typická temporálnost', ale aj kauzalita. Lyrika oproti epike temporálnost’ narúša. Ako hovorí švajčiarsky literárny vedec Emil Staiger, lyrický štýl je spomienkou. ${ }^{9}$ Americký lingvista Roman Osipovič Jakobson práve v súvislosti so silnou koexistenciou a interferovaním literárnych štruktúr (predovšetkým epických) do štruktúr filmových, ale aj naopak, poukazuje na metonymický charakter filmového diela. ${ }^{10}$ Francúzsky filozof, filmový teoretik Gilles Deleuze však v tejto súvislosti upozorňuje na silu imaginárnosti filmovej skladby, syntaxe filmového artefaktu, ktorý v sebe spája metonymický aj metaforický princíp: „Film nemôže povedat ako

\footnotetext{
${ }^{8}$ Operatívnost' v zmysle adresnost', priamočiarost'. Viac o operatívnosti jazyka pozri LOTMAN, J. M. Struktura chudožestvennogo teksta. Moskva : Izdatel'stvo Iskusstvo, 1970.

${ }^{9}$ KRAUSOVÁ, N. Epika a román. Bratislava : Slovenský spisovatel', 1964, s. 49.

${ }^{10} \mathrm{O}$ metonýmii a metafore vo filmovej skladbe v súvislosti s úvahami R. Jakobsona píše J. Pašteka. Pozri PAŠTEKA, J. Estetické paralely. Bratislava: Veda, s. 292.
} 
básnik: ,ruky poletujú'; musí najprv ukázał’ ruky, ktoré sa rýchlo pohybujú, a potom poletujúce lístie. Toto obmedzenie však platí čiastočne. Je pravdivé, pokial' kinematografický obraz prirovnávame k výpovedi. Neplatí však, ak si vezmeme kinematografický obraz ako to, čím je - ako obraz - pohyb, ktorý nielenže pohyb rozdeluje tým, že ho vztahuje k objektom, medzi ktorými sa konštituuje (metonymia, ktorá obrazy oddel'uje), ale ktorý zároveň môže pohyb zlievat tým, že ho vztahuje k celku, ktorý vyjadruje (metafora, ktorá obrazy zjednocuje). ${ }^{" 11}$

Týmto genologickým úvodom sme chceli poukázat’ na to, že romantické obdobie výrazne akcentovalo lyriku - a práve prvky lyriky sa transformujú do rôznych rovín tých filmových diel, ktoré sú inšpirované romantickým obdobím. Obdobie romantizmu je $\mathrm{v}$ histórii (predovšetkým literárneho) umenia dôležitým medzníkom, ked' sa výrazne narušila staršia štruktúra kreovania epického sujetu založená na parataktickom, lineárnom budovaní problémových situácií. Dôležitým aspektom v druhej polovici 18. až začiatkom 19. storočia bol aj fakt, že v spoločenskom priestore nadobúdala výraznú pozíciu stredná vrstva, preto môžeme v tomto období po prvýkrát v kontexte literatúry hovorił’ o existencii populárnej literatúry (hororové, detektívne poviedky, sentimentálny - ženský román), ktorá v tejto societe našla svojich čitatel’ov.

\section{Klasicizmus vs. romantizmu}

Kým klasicizmus, ale aj v širšom kontexte osvietenstvo, na rozdiel od stredovekého duchovného spiritualizmu preferovalo exaktnost' a poznanie s mottom "sapare aude" (odvaha poznat') ${ }^{12}$, tak literatúra romantizmu tento princíp rácia opúšta. V romantizme už nie je dominantné vnímanie reality v jej harmónii tak ako to bolo v klasicistickom období, ale prevažuje antitetický princíp vnímania sveta. Zatial' čo v období klasicizmu je základným znakom princíp monumentalizmu a idyly vo svojej statickej povahe, tak pre romantizmus je základnou entitou fluktuačný princíp, dynamickost’ v obrazovej aj motivickej vrstve. Žáner ako klasicistická elégia a óda sa prekonáva, romantický autor je introvertnejší, často využíva pochmúrnu, temnú atmosféru v tragickom epilógu. Romantická generácia, tak ako každá iná, vidí svet po svojom a väčšinou v protiklade s generáciou predchádzajúcou. Snaží si vytvárat' veci v novom poriadku, definovat ich v novej konštelácii, v novej básnickej reči preto, lebo aj napriek tvrdeniu, že sa literatúra nevyvíja, básnický jazyk môže zostarnút. Podla slovenského literárneho vedca Alexandra Matušku, v romantizme „poézia prestáva byt’ zábavkou a cvičením, stáva sa poslaním a osudom. Západný romantizmus priniesol v opozícii voči klasicizmu významné nóvum, ked' klasického abstraktného člo-

${ }^{11}$ DELEUZE, G. Cinéma 2. L'image-temps. Paris : Les édition de minuit, 1985. Cit. podla českého prekladu: DELUZE, G. Film 2. Obraz - čas. Praha : Národní filmový archiv, 2006, s. 191 - 192.

${ }^{12}$ Alfred de Musset v jednom zo svojich listov píše:. „Náhle však (asi v roku 1828) sme sa dozvedeli, že existujú romantická a klasická poézia, romantický a klasický román, romantická a klasická óda; ba čo vravím, drahý môj pane, že aj samotný verš môže byt̉ romantický alebo klasický, podl’a toho, ako ho chápeme. Ked’ sa k nám doniesla táto zvest', celé noci sme nespali. Dva roky pokoja a istoty boli preč ako púhy sen. Všetky naše úvahy ovládol zmätok: ak už nevytvoria demarkačnú líniu medzi oboma tábormi Aristotelove pravidlá, podl’a čoho sa máme orientovat', na čo sa máme spol’ahnút? Ako máme poznat', ku ktorej škole patrí literárne dielo, ktoré čítame? Mysleli sme si, že zasvätenci v Paríži musia mat' nejakú formulku, ktorá ten problém rýchlo vyrieši, ale čo máme robit my na vidieku? A musím Vám povedat', pane, že u nás má slovo romantický l'ahko pochopitel’ný význam - je synonymom absurdného a nikto sa oň zvlášt nestará (...).“ Cit. podl'a HRBATA, Z. - PROCHÁZKA, M. Romantismus a romantismy. Praha : Karolinum, 2006, s. 290. 
veka, ktorý mal všetko spoločné s ostatnými l’ud’mi a ktorý v sebe vo zvýšenej miere zahŕňal všetko všeobecne človečenské, nahradil iným človekom - individualistom, ktorý nehl'adá to, čo ho s ostatnými l'ud’mi spája, lež to, čo ho od nich dištancuje. " 13

Madame de Staël, predstavitel'ka liberálneho romantizmu, t. j. romantizmu odmietajúceho prvky mysticizmu, ktorá priniesla francúzskej kultúrnej societe povedomie o nemeckom romantizme, rozdeluje francúzsku literatúru na literatúru juhu a severu. Južný typ literatúry definuje ako typ ovplyvnený stredomorskou (antickou) literatúrou, severský typ je podl'a nej ovplyvnený severskou literatúrou (William Shakespeare, Friedrich Schiller a i.). Tým, že južný typ inklinuje ku klasicizmu, nemá podl'a nej potenciál ponúknut niečo moderné. Naopak, severský typ inklinuje k romantizmu a tým otvára možnost’ modernej umeleckej realizácie. Klasicistická estetická forma je charakteristická svojou uzavretostou. Ciel' hl'adá skôr v slove, nie vo vonkajšom svete, ktorý by bol v symbióze s mýtickou híbkou básnikovho Ja. V tomto kontexte Howard Phillip Lovecraft, americký autor sci-fi, fantasy a hororov, dodáva: „,Kedykol'vek sa prejavila mystická nordická krv, atmosféra l’udových príbehov získala na sile. Na druhej strane vo všetkých románskych národoch preniká na povrch stopa elementárnej racionality, ktorá i vo svojich najzvláštnejších poverách popiera žiarivé záchvevy charakteristické pre dávne legendy zrodené uprostred večného ladu a hlbokých lesov. "14

V súvislosti s atmosférou romantizmu treba spomenút znovuoživenie stredovekej mystiky. Romantizmus sa popri inom inšpiroval rozpadávajúcimi sa stavbami stredovekej kultúry a architektúry. Atmosféra stredovekých ruín bola v príkrom kontraste s vel'kolepostou a dokonalostou línií klasicistickej architektúry, ovplyvnenej starovekým kultom gréckeho a rímskeho sveta. Zrúcaniny stredovekých chrámov či hradov sa stali pre romantické umenie dokonalou inšpiráciou. Romantizmus zachytával pominutel'nost' l'udského života v kontraste s univerzálnostou, ale aj osudovost’ou, a to predovšetkým v mesianistickom prúde literatúry. Autori romantizmu sa snažili zachytit’ pocit strachu a napätia, bizarnost’ alegorických postáv postmortálneho sveta. Teda nie vznešenost' a aristokratickost', nie rovné, presvetlené línie, nie ódu alebo selanku ako žáner, ale skalnaté útesy so svojou pochmúrnostou, život človeka ohrozený búrlivými nástrahami prírody či temnotami ludskej duše.

Ak spomíname základné motívy romantickej literatúry, nemôžeme obíst’ motív lásky. Romantická láska je špecifickým citom - nie je pudová, erotická ani pragmatická, nevzniká v politických a spoločenských debatách na večierkoch urodzených dám, ako to možno pozorovat’ vo francúzskych románoch a filmoch inšpirovaných obdobím klasicizmu. Už citovaný Maarten Doorman poukazuje na prvú scénu vo filme Nebezpečné známosti (Dangerous Liaisons, 1988, réžia Stephen Frears), ktorý je adaptáciou rovnomenného románu Pierra Choderlos de Laclosa. Hlavní predstavitelia, Valmont aj markíza de Merteuil, sa dôkladne líčia, obaja sa pripravujú na večierok, ktorý by mal byt’ oslavou ich života, ale divák sa nemôže ubránit dojmu, že si práve obliekajú vojenskú zbroj. Je to zobrazenie človeka nie kým je, ale koho predstavuje. Ako upozorňuje Doorman, nie je podstatné vyjadrit’ v tomto okamihu

\footnotetext{
${ }^{13}$ MATUŠKA, A. Dielo II. Bratislava : Tatran, 1990, s. 112 - 113.

${ }^{14}$ LOVECRAFT, H. P. Supernatural Horror in Literature. New York : Dover publications, 1973. Cit. podla slovenského prekladu: LOVECRAFT, H. P. Nadprirodzená hrôza v literatúre. Bratislava - Pezinok : Agentúra Fischer-Formát, 1997, s. 14.
} 
podstatu autentickej osobnosti, ale zaujat’ v správny okamih správnu pózu. Samotné líčenie je maska, ktorou postava zahal'uje svoje Ja. Valmontovým ciel'om je uspokojit’ seba samého, svoje sexuálne chute v rôznych mileneckých avantúrach: „(...) ostatní ludia nepredstavujú v rámci podobnej antropológie indivíduá s rovnakými právami, ale predovšetkým prostriedky k uspokojeniu vlastných túžob." ${ }^{15}$

Naproti tomu, pravá romantická láska je plná vášne a citu. Zároveň je to láska tragická, nenaplnená, zavŕšená v osude Romea a Júlie, ktorý sa stal mýtom v širokom kultúrnom kontexte. Nájdeme ju aj v románe Victora Huga Chrám Matky Božej v Parí$z ̌ i$, v postave fyzického mrzáka Quasimoda, žijúceho na najfrekventovanejšom mieste v Pariži, no zároveň v tých najvyšších útrobách chrámu Notre-Dame, tak vzdialeného od sveta človeka.

Ak hovoríme o romantických inšpiráciách vo filmovej tvorbe, v prvom rade máme na mysli filmové adaptácie literárnych textov tohto obdobia. Prirodzene, filmová tvorba sa inšpiruje predovšetkým prozaickou tvorbou. ${ }^{16}$ No jedným z typických žánrov romantického obdobia je balada, pričom prepis tohto žánru je vo filmovej tvorbe ojedinelý. K zriedkavým príspevkom patrí filmová adaptácia baladických textov českého spisovatel’a Karla Jaromíra Erbena Kytice režisérom Františkom A. Brabcom (2001). Režisér a kameraman v jednej osobe realizoval klipovitú formu siedmich uzavretých príbehov, ktoré priradil lineárne k sebe, vytvoriac tak parataktickú štruktúru filmového diela. Štruktúra romantickej balady je oproti l'udovej balade bohatšia, predovšetkým v zmysle využívania básnických figúr a originálnosti autorského jazyka. Tak ako v samotných Erbenových baladách, aj v ich filmovej adaptácii (vo vizuálnej rovine filmového jazyka) sú bohato využívané znaky, symboly, básnické (metaforické) figúry. Pre percipienta je to markantné práve v obrazovej zložke filmu, ktorá pracuje s pestrou farebnostou. To často vytvára pocit expresívnosti, kontrastujúci s impresionistickou náladou „bezproblémovosti“ (napr. v balade Vodník), farby sú zároveň využívané ako dôležitý kód pri percepcii filmového diela. ${ }^{17}$ Kontrast, ktorý je jedným zo základných princípov pri budovaní baladického textu v romantickej literatúre, je obrazne umocnený aj v adaptovanom filmovom diele. Frekventovane sa využíva napríklad opozícia: deň (svetlo) - noc (tma, spln). Ide o klasický, až archetypálny kontrastný princíp, ktorý sa nachádza aj v l'udovej slovesnosti a v rano-stredovekých textoch a vychádza z prirodzeného l’udského strachu z tmy, z niečoho nepoznaného.

Howard Phillip Lovecraft tvrdí: „Hocako vel'ká racionalizácia, reforma myslenia či freudovská analýza preto nedokážu celkom potlačit rozochvenie z príbehov rozprávaných pri praskajúcom kozube či strachu z opusteného lesa. Ide tu o psychologický archetyp alebo tradíciu, (...). ${ }^{\text {"18 }}$ Vzápätí dodáva, že „deti sa vždy budú bát tmy

${ }^{15}$ DOORMAN, M. Romantický ř́a, s. 26.

${ }^{16} \mathrm{~V}$ tomto kontexte opät’ spomeňme adaptácie klasického románu tohto obdobia, Hugovho Chrámu Matky Božej v Paríżi, napr. film Notre Dame de Paris (1957, réžia Jean Delannoy) či animovaný film The Hunchback of Notre Dame (1996, réžia Kirk Wise, Gary Trousdale).

${ }^{17}$ Napríklad zatial čo pôvodný baladický verš v balade Vodník využíva fenomén bielej farby ako farby čistoty a nevinnosti, panenstva, ale zároveň s ambivalentým charakterom, a to symbolikou smrti (Perly jsem tobě vybírala, / bíle jsem tebe oblíkala, / v sukničku jako z vodních pěn: / nechod', dceruško, k vodě ven. / Bílé šatičky smutek tají, / v perlách se slzy ukrývají, / a pátek neštastný je den, / nechod', dceruško, k vodě ven. "), tak film vizuálne vytvára bohatšiu škálu farebnosti a kontrastnosti.

${ }^{18}$ LOVECRAFT, H. P. Nadprirodzená hrôza v literatúre, s. 6. 
a l’udia citliví na dedičný impulz sa vždy zachvejú pri pomyslení na skryté bezhraničné svety podivného života, ktorý možno pulzuje kdesi d’aleko, v priepastiach za hviezdami, alebo desivo pôsobí na našu planétu, s obludnostou, ktorej nečisté rozmery dokážu prehliadnut iba mŕtvi či šialenci. " 19

Filmový jazyk pracuje so znakmi, ktoré vytvárajú vo vzájomnej paradigme rôzne konotácie. Znakové štruktúry ${ }^{20}$ tak vo filmovom zábere nemusia byt' nositel'mi sémantickej informácie len v izolovanej pozícii, teda stojace samy osebe a pre seba, ale často takúto informáciu ponúkajú až v kontexte filmovej skladby, syntaxe. Podl’a Jurija Lotmana, „Socha hodená do trávy môže vytvorit nový umelecký efekt vzhl'adom na vznik vzájomného vztahu medzi trávou a mramorom. Táto zvláštnost’ sa spája (...) so štruktúrnym princípom, ktorý určuje mnohoznačnost̉ umeleckých prvkov; nové štruktúry svojím vstupom do textu alebo do mimotextového pozadia umeleckého diela nerušia staré významy, ale vstupujú s nimi do nových sémantických vztahov. "21 Vo filme Kytice spája samostatné baladické útvary do výsledného filmového tvaru spona - postava paholka hrajúca na píštalke, ktorá je nositel’om hudobného motívu a má rámcujúci charakter s odkazom na spievaný charakter pôvodných baladických textov.

\section{Mystika stredoveku}

Princípy iracionality a transcendenta, ktoré sú frekventovane v romantickej literatúre, sú zároveň archetypálnym spôsobom zakorenené v genetike európskej, ale aj svetovej literatúry a kultúry. Bazálne znaky umenia kreujú prakticky až do obdobia osvietenstva, ked' filozofické prúdy na čele s ateistickými encyklopedistami Montesquieuom, Jeanom le Rond d'Alembertom a Denisom Diderotom po prvýkrát v dejinách ludstva významným spôsobom relativizujú stredovekú teológiu. Osvietenský princíp s výrazným pertraktovaním racionalizmu atakuje práve stredovekú scholastiku. V d’alšom, romantickom období sa však fenomén mysticizmu vracia spät’ do umenia, a to aj vo folklorizujúcom tvare. Fenomény mystiky, iracionality, transcendenta vždy boli a zrejme aj budú viac či menej prítomné v umení a v kultúre už len preto, lebo sú vo všeobecnosti neodmyslitel’nou súčastou, sui generis, podstatou l'udského vedomia - a práve tieto fenomény sú výrazne zakotvené v romantickom umení.

Je symptomatické, že stredoveká kultúra s atmosférou mystiky, tak frapantne určená monumentálnostou architektúry gotiky s pocitom pompéznosti, sa stala častou inšpiráciou pre filmové umenie. No nie je to len samotnou vizuálnou prítažlivostou

\footnotetext{
${ }^{19}$ Tamže, s. 8 .

${ }^{20}$ „Barthes rozlišuje lingvistické (symbol) a psychologické (analogón) chápanie znaku. Nehovorí o znaku, pretože koncept konvenčného znaku považuje vzhl'adom na obrazovú podstatu filmu za nedostatočný. Nahrádza ho pojmom psychologického analogónu (v zmysle: obraz analogický realite) chápaného ako znak vel’mi špecifický. Súvisí to s Mitryho známym výrokom o tom, že film nemá jazyk: ,Film nie je lingvistický systém znakov a symbolov, ako estetickú formu výrazu používa obrazy, ktoré samy osebe sú prostriedkom expresie. V súlade s typom rozprávania sa organizujú do systému znakov a symbolov, teda jazyk tvoria. Ale je to jazyk druhého stupňa, umelecký jazyk, lebo existuje výlučne v systéme vnútornej organizácie, ktorou je dielo. Neexistuje pred dielom ani mimo neho." Pozri CIEL, M. Pohyblivé obrázky. Levice : Koloman Kertézs Bagala, 2006, s. 120. s. 95 .

${ }^{21}$ Cit. podla slovenského prekladu: LOTMAN, J. Štruktúra umeleckého textu. Bratislava : Tatran, 1990,
} 
členitosti architektonickej štruktúry pre oko kamery, ale aj samotným historickým faktom, kulturologickým, ale zároveň antropologickým prvkom, definujúcim stredoveký ponor do mysticizmu v gotickom období v bipolárnej opozícii svetské vs. duchovné. Gotika je tak definíciou vel'koleposti a nesmrtel'nosti božského, „vel'kého“, vznešeného, teda duchovného, stojaceho v opozícii voči „malému“, hriešnemu, teda svetskému. Gotické katedrály vzbudzujú u návštevníka pocit úcty, ale aj pokory, úteku od každodenného života.

Victor Hugo v predslove svojho románu píše: „Chrám Matky Božej v Paríži azda odkryl niekol'ko pravdivých pohladov na stredoveké umenie, na toto obdivuhodné umenie, ktoré jedni až dosial' nepoznajú a druhí, čo je ešte horšie, neuznávajú. Autor si však vôbec nemyslí, že splnil úlohu, ktorú si dobrovol’ne vytýčil. Už pri nejednej príležitosti obhajoval našu starú architektúru, verejne pranieroval nejedno zhanobenie, nejedno zrúcanie, nejedno zneuctenie. V tom neustane! (...) Naše historické stavby bude práve tak neúnavne bránit', ako zúrivo útočia na ne obrazoborci našich škôl a akadémií. Pretože človeka zarmucuje, ked' vidí, do akých rúk sa dostalo stredoveké stavitel'stvo a ako dnešní fušeri zaobchádzajú s troskami tohto vel'kého umenia." 22

Nemecký básnik a kritik August Wilhelm Schlegel v tomto kontexte konštatuje: „Ked’ sa po znovuoživení klasického staroveku začala napodobňovat’ aj grécka architektúra, často až privel'mi nevhodne, bez ohl'adu na odlišne podnebie, mravy a určenie budov, horlivci za tento nový vkus úplne zatracovali gotické stavitel'ské umenie, vyčítali mu, že je nevkusné, ponuré, barbarské. Najskôr sa dalo prepáčit Talianom; vd’aka zvyškom stavieb, ktoré zdedili po starých a klimatickej spriaznenosti s Grékmi a Rimanmi, akoby mali v krvi zál'ubu v starej architektúre. My severania si však nedáme len tak l’ahko odškriepit’ intenzívne vážne dojmy, ktoré sa človeka zmocňujú pri vstupe do gotického dómu. “23 Režisér Ingmar Bergman vo svojich poznámkach k scenáru filmu Siedma pečat' (Det sjunde inseglet, 1957), ktorý je popretkávaný stredovekým mysticizmom, uvádza: „Na otázku, aký je ciel’ mojich filmov, by som teda mohol odpovedat: ,Chcem byt jedným z robotníkov pracujúcich na katedrále, ktorá sa týči na planine. Chem sa venovat’ tomu, že budem z kameňa tesał hlavu draka, anjela či démona, ale snád’ svätca - nezáleží na tom, vo všetkých prípadoch budem pocitovat’ rovnaké potešenie. Či som veriaci alebo neveriaci, krestan či pohan, pracujem s ostatnými na stavbe katedrály. “ ${ }^{24}$

V období, ked’ ešte nebola rozšírená kníhtlač, mohli práve stavitelia stredovekých chrámov prostredníctvom architektúry po prvýkrát výrazne, ale predovšetkým verejne prezentovat' fenomén pekla, groteskných postavičiek, démonov a skrze nich vytvorit atmosféru mystiky, strachu z „pekelného“ postmortálneho priestoru. Táto vizualizácia hriechu cez podobu démonických chrličov ${ }^{25}$ na fasádach gotických chrá-

\footnotetext{
${ }^{22}$ Poznámka k definitívnemu vydaniu románu z roku 1832.

${ }^{23}$ ŽITNÝ, M. (ed.). Nemeckí romantici, s. 132.

${ }^{24}$ BRAGG, M. The Seventh Seal. London : British Film Institute, 1993. Cit. podla českého prekladu: BRAGG, M. Sedmá pečet’. Praha : Casablanca, 2011, s. 10.

${ }^{25}$ Jeden z hlavných predstavitelov krestanskej stredovekej filozofie 12. storočia Bernard z Clairvauxu podrobil groteskné výrazy na fasádach gotických stavieb kritike, považoval ich zobrazenie za nečisté. Podl’a Clairvauxa boli takmer modlami. „Čo napokon v kláštoroch, kde mnísi spoločne čítajú, má čo robit všetka tá smiešna obludnost', prapodivne spotvorená krása a krásna spotvorenost? Čo tam robia tie nečisté opice? Nelútostné levy? Obludní kentaurovia? Bytosti, ktoré sú len napol l’ud’mi? Škvrnité tigre? Vojaci pri šarvátke?
} 
mov znázorňovala kontrast sveta vonkajškového s vnútorným (v animovanom filme Zvonár u Matky Božej ${ }^{26}$ sú chrliče postavami, ktoré dostanú antropomorfný charakter vo svojej grotesknej polohe). Zároveň odkazovala na svet svetský, v ktorom na l'udí číha hriech, démoni podsvetia. Ale príchodom do chrámu akoby človek získaval pocit vel'koleposti a zároveň pokory, ako keby gotická katedrála poukazovala na to, že tam vonku je svet pokušenia, tu vo vnútri svet viery; vstup do chrámu je teda krokom k viere, krokom od pozemského sveta hriechu k svetu svätému, k očistcu, krokom k spáse. Tam vonku človeka ohrozuje hriech, ale jeho úlohou je pozerat’ sa hore, k nebu, vnútorne aj duchovne. Kríž vládne nad všetkými, aj nad peklom, preto musí byt’ symbolom, ktorý sa týči nad chrámom.

Ak je kompozícia katedrály vo vizuálnom tvare obrátená (symbol obeseného za nohu v tarotových kartách), tak ako je to filme Ako prichádzajú sny (What Dreams May Come, 1998, réžia Vincent Ward), sémanticky kóduje symbol obrátenosti hodnôt u človeka, smrt', životný krach, tu konkrétne líniu postavy samovraha. Kríž sa týmto vertikálnym posunom nenachádza na vrchole, ale pri nohách, ako metafora padlého anjela. Spomenutý film zaujímavým vizuálnym spôsobom využíva d’alšie znaky: topos podsvetia ukrytý pod zemou pred zrakmi človeka, jaskyňu, podzemné tunely (s alúziou na rieku Styx v gréckej mytológii), paru vychádzajúcu zo zeme či sopky (ktoré sú už od starovekých čias symbolom smrti, záhuby, predobrazom pekla) chrliace oheň a síru. Červená a čierna farba, ktorá má ambivalentnú sémantickú výpoved' (symbolika krvi ale i smrti), je v kontraste s modrou a bielou farbou, symbolizujúcimi harmóniu, pokoj a čistotu. Nebo, antagonistické k priestoru pekla, je zároveň klasickým symbolom večného života, spásy, viery, duchovnosti. Vo filme je zvýraznené impresionistickou atmosférou: aj v pominutel'nej chvíl'ke sa dá nájst' krása a harmónia.

Ďalším dielom, inšpirovaným stredovekou atmosférou, je román Umberta Eca Meno ruže (The Name of the Rose, 1980). Jeho filmová adaptácia (1986, réžia Jean-Jacques Annaud), ktorá výrazným spôsobom vychádza z knižnej predlohy, atmosféru stredovekého obdobia umocňuje. Eco využil poetický plán romantickej literatúry vo viacerých rovinách. Ako vedec, literárny teoretik a semiotik zaoberajúci sa stredovekou literatúrou a filozofiou, inšpiroval sa stredovekým umením, podobne ako to bolo v období romantizmu. Jeho postmoderný román aj filmová adaptácia sú plné intertextuality a sledujú známe žánrové vzorce: mnísi zomierajúci za zvláštnych okolností, ktorých smrt’ vyšetruje detektív William z Baskerville, jeho pomocník Adso z Melku je akýmsi doktorom Watsonom. William v priebehu siedmich dní odhal'uje zločiny, ktoré sú alúziou na biblických sedem smrtelných hriechov. Samotný román je eklektický, podobne ako stredovek, ktorý Eco vedecky skúmal, pričom využíva základné kompozičné postupy, s ktorými pracuje aj romantická literatúra: kláštor ako priestor mysticizmu, iracionality, duchovného a subjektívneho; priestor kláštora usadený d’aleko od civilizácie a v kontraste s toposom mesta postavený vysoko na skale, t. j. blízko k Bohu; detektívny princíp; čas stredoveku s architektúrou gotiky; postavy reprezentujúce transcendentno, duchovno; horálny (magický) čas atd’.

Lovci trúbiaci na rohoch? Vidíme tu niekolko tiel s jedinou hlavou a naopak, mnoho hláv na jednom tele." Pozri ECO, U. Arte e bellezza nell'estetica medievale. Milan : Bompiani, 1997. Cit. podl'a českého prekladu: ECO, U. Umění a krása ve středověké estetice. Praha : Argo 1998, s. 18.

${ }^{26}$ V origináli The Hunchback of Notre Dame, Walt Disney Feature Animation, 1996. 
Mystérium stredovekej atmosféry sa dostáva v 18. a 19. storočí aj do populárnej literatúry, v podobe tajomna, folklórnych inšpirácií, sveta čarodejníc, duchov, archetypálneho strachu z nepoznaného, z tmy. No zároveň romantizmus prichádza aj s inovatívnymi prístupmi v rovine témy. Mary Shellyová neponúkla čitatel'om vo svoj románe Frankenstein (Frankenstein, or The Modern Prometheus, 1818) len mainstreamovú zábavku s nádychom hororovosti a tajuplnosti, ale zároveň vztýčila prst, možno po prvýkrát v v dejinách umeleckej literatúry, pred zneužívaním moderných technológií človekom, ktorý sa chce hrat na novodobého stvoritela a spasitela. Román sa stal oblúbenou predlohou pre filmové stvárnenie, pričom prakticky všetky filmové adaptácie preberajú motívy literárnej predlohy, no predovšetkým jej posolstvo: otázky, ktoré pred človeka nastol'uje vedecko-technický pokrok.

Koniec feudálneho systému a nástup novej priemyselnej doby mal vplyv aj na percepciu literatúry. V ovel’a väčšej miere než v predošlom období vzrástol vd’aka gramotnosti obyvatel'stva okruh čitatel'ov, ktorí siahali predovšetkým po masovej, populárnej literatúre. V období romantizmu sa tak mohol výraznejšie rozšírit aj záujem o ludovú literatúru, hororové, prípadne detektívne poviedky. Devätnáste storočie bolo storočím priemyselnej revolúcie. Vynález elektriny, objavy v medicínskych i prírodných vedách a využívanie nových technológií znamenali významný posun vo vývine spoločnosti. Tieto skutočnosti zároveň priniesli nové témy, ale aj otázky súvisiace s existenciou človeka a jeho vztahom k univerzu, k Bohu. Shellyovej román ponúka práve spojenie stredovekej, gotickej atmosféry s filozofickými, ale aj etickými otázkami, ked’ poukazuje na možné negatívne stránky technologického pokroku. Upozorňuje na to, že technika sa môže vymknút l'udskej kontrole, i na to, že využívanie nových technológií a vynálezov je aj o morálnej zodpovednosti, nielen o túžbe po skúmaní nových dimenzií. Gróf Frankenstein je prototypom osvieteného človeka, prezentujúceho vo svojej dobe túžbu l’udstva po poznaní a fascináciu novými vynálezmi a technológiami.

Filmové adaptácie Frankensteina ponúkajú nadčasovo aktuálne filozofické otázky o využívaní i možnom zneužívaní nových objavov, ktoré sú pertraktované v umení od romantického obdobia až dodnes. V súčasnej audiovizuálnej tvorbe tento problém rezonuje vo viacerých filmoch, napríklad v A. I. Umelá inteligencia (Artificial Intelligence: AI, 2001, réžia Steven Spielberg) alebo Ex Machina (2014, réžia Alex Garland). Sú apelatívnym mementom toho, kam až môže siahat' využívanie nových technológií, ak nie sú zodpovedané základné etické otázky, ktoré l’udstvu tento pokrok prináša. Možnosti výskumu zároveň iniciujú snahu racionálne zdôvodňovat' bazálne princípy l’udského bytia, vrátane existencie človeka, viery, rácia a transcendentna. Gróf Frankenstein „,vytvára" novodobého Adama, no z neho samotného sa nestane stvoritel', ale skôr padlý anjel. Vo filme Ex Machina je to nová počítačová technológia, ktorá umožní programátorom stał’ sa "stvoritel'om“. Ale ich frankensteinovský počin, z ktorého vzniká nová identita - robot s l'udskou tvárou, s l'udským uvažovaním a s emóciami, prináša skazu. Hlavná hrdinka Ava, ktorá menom pripomína Adama a Evu, je alúziou na biblické vyhostenie z raja. Presiahla odbornost' svojho tvorcu, vymkla sa spod kontroly, za čo logicky prichádza trest: smrt’ programátora. Ex Machina je špekulatívnou, strašidelnou fikciou, zároveň však úplne prijatel’nou a presvedčivou. Je to film o stvorení umelej inteligencie, ktorý zároveň poukazuje na fakt, že aj ked' sa technika vyvíja a elektrinu z čias Frankensteina vystriedala počítačová technológia Ava, základné ludské vlastnosti, emócie a túžby sa v priebehu dejín zrejme nemenia. 


\section{Záver}

Obdobie romantizmu zadefinovalo charakter základných žánrov populárnej literatúry v dnešnej podobe: detektívneho románu/poviedky, hororovej literatúry, gotického románu, ale aj sentimentálnej literatúry, ktorej počiatky môžeme vidiet' už v období klasicizmu a preromantizmu, napríklad v tvorbe Jane Austenovej. Audiovizuálna tvorba sa však neinšpiruje iba literárnymi prototextami, ktoré transferujú text do filmovej, prípadne televíznej podoby. Je výrazným spôsobom inšpirovaná aj univerzálnymi postupmi a prvkami romantického obdobia v širšom kulturologickom, historickom a filozofickom kontexte. V súčasnosti na VOD (Netflix, HBO, Prime video a d’alšie) vidíme markantný nástup detektívnych príbehov s prvkami magiky, iracionality, pochmúrnosti, romantickej mystiky. Spoločnost' Netflix priniesla najnovšiu dvanást’dielnu sériu inšpirovanú románom Frankenstein pod názvom The Frankenstein Chronicle. Aj v súčasnosti pripravovaný seriál Assassin Creed II, ktorý je adaptáciou svetovo známej počítačovej hry, potvrdzuje tézu, že základné princípy romantickej poetiky a filozofie sa intenzívnym spôsobom etablujú i v súčasnej audiovizuálnej tvorbe, pričom sa dá predpokladat', že budú výraznou inšpiráciou pre filmových tvorcov aj v budúcnosti.

\section{THE PHENOMENON OF ROMANTICISM IN A CINEMATOGRAPHIC WORK}

\section{Ján SABOL}

The study deals with the influence of Romantic poetics (or the poetics of the Romantic period) on audio-visual production. In this context, the author not only mentions some film adaptations of literary models from the Romantic period, but also points out the basic genological principles of this period and, in a broader literary and cultural context, the cultural and social influences at the turn of the 18th and 19th centuries on the art of the Romantic period. The study does not aspire to comprehensively capture the issues of the influence of Romantic poetics on audio-visual production, it only outlines some of the tendencies that are discernible in filmmaking and that have their roots in Romanticism, but also in medieval art, which became a major inspiration for the Romantic period.

Príspevok vznikol v rámci projektu APVV 19-0244 Metodologické postupy v literárnovednom výskume s presahom do mediálneho prostredia.

\section{LITERATÚRA}

BARTHES, Roland. Rozkoš z textu. Bratislava : Slovenský spisovatel', 1994. 192 s. ISBN 80-2200567-3.

BIEDERMANN, Hans. Lexikón symbolov. Bratislava : Obzor, 1992. 373 s. ISBN 80-215-0217-7. BRAGG, Melvyn. Sedmá pečet'. Praha : British Film Institute, 1993. 87 s. ISBN 978-80-87292-08-2.

CIEL, Martin. Pohyblivé obrázky. Levice : Koloman Kertézs Bagala, 2006. 149 s. ISBN 8089129692. DELEUZE, Gilles. Film 1. obraz - pohyb. Praha : Národní filmový archiv, 2000. 298 s. ISBN 807004-098-X. 
DELEUZE, Gilles. Film 2. obraz - čas. Praha : Národní filmový archiv, 2006. 376 s. ISBN 80-7004127-7.

DOORMAN, Maarten. Romantický řád. Praha : Prostor, 2008. 312 s. ISBN 978-80-7260-191-2.

ECO, Umberto. Interpretácia a nadinterpretácia. Bratislava : Archa, 1995. 146 s. ISBN 80-7115-080-0.

ECO, Umberto. Meno ruže. Bratislava : Slovart, 2012. 177 s. ISBN 978-80-566-0698-9.

ECO, Umberto. Umění a krása ve středověké estetice. Praha : Argo, 2007. 227 s. ISBN 978-80-7203892-3.

HELMANOVÁ, Alicja. Tvořivá zrada. Filmové adaptace literárních děl. In Tvořivé zrady. Současné polské myšlení o filmu a audiovizuální kultuře. Praha : Národní filmový archiv, 2005, s. 13 - 144. ISBN 80-7004-119-6.

HEGEL, Georg Wilhelm Friedrich. Estetika II. Bratislava : Epocha, 1970. $464 \mathrm{~s}$.

HUGO, Victor. Chrám Matky Božej v Pariži. Bratislava : Slovenský spisovatel', 1963. $536 \mathrm{~s}$.

HRBATA, Zdeněk - PROCHÁZKA, Martin. Romantismus a romantismy: pojmy, proudy, kontexty. Praha : Karolinum, 2006. 417 s. ISBN 8024610604.

KRAUSOVÁ, Nora. Epika a román. Bratislava : Slovenský spisovatel', 1964. 168 s.

LEŠČÁK, Milan - SIROVÁTKA, Oldřich. Folklór a folkloristika. O l’udovej slovesnosti. Bratislava : Smena, 1982. $259 \mathrm{~s}$.

LOTMAN, Michajlovič, Jurij. Štruktúra umeleckého textu. Bratislava : Tatran, 1990. 373 s. ISBN 80-222-0188-X.

LOTMAN, Michajlovič, Jurij. Semiotika filmu a problémy filmovej estetiky. Bratislava : Slovenský filmový ústav, 2008. 139 s. ISBN 978-80-85187-51-9.

LOVECRAFT, Howard Phillips. Nadprirodzená hrôza v literatúre. Bratislava-Pezinok : Agentúra Fischer-Formát, 1997. 116 s. ISBN 80-967 229-2-1.

MATUŠKA, Alexander. Dielo II. Bratislava : Tatran, 1990. 555 s. ISBN 80-222-0218-5.

MATUŠKA, Alexander. O romantizme. In ČEPAN, Oskár (ed.). Litteraria XVI. Bratislava : Veda, 1974, s. 5 - 17.

MIHÁLIK, Peter. Kapitoly z filmovej teórie. Bratislava : Tatran, 1983. 236 s.

MIKO, František. Od epiky k lyrike. Štylistické prierezy literatúrou. Bratislava : Tatran, 1973. $292 \mathrm{~s}$.

MIKO František. Umenie lyriky. Bratislava : Slovenský spisovatel', 1988. $280 \mathrm{~s}$.

PAŠTEKA, Július. Estetické paralely umenia. Bratislava : VEDA, 1976. $425 \mathrm{~s}$.

STAIGER, Emil. Základní pojmy poetiky. Praha : Československý spisovatel, 1969. 189 s.

STADTRUCKER, Ivan. Dramaturgia hraného filmu. Bratislava : Tatran 1990. 277 s. ISBN 80-2220172-3.

TIEGHEM, Philippe Van. Les Grandes Doctrines Littéraires en France. Paris : Presses Universitaires de France, 1993. 320 s. ISBN 978-2-13-045659-9.

ŽITNÝ, Milan (ed.). Nemeckí romantici. Bratislava : Tatran, 1989. 392 s. ISBN 80-222-0001-8.

Ján Sabol

Katedra slovakistiky, slovanských štúdií a komunikácie

Filozofická fakulta

Univerzita Pavla Jozefa Šafárika v Košiciach

Šrobárova 2

04059 Košice

e-mail: jan.sabol@upjs.sk 